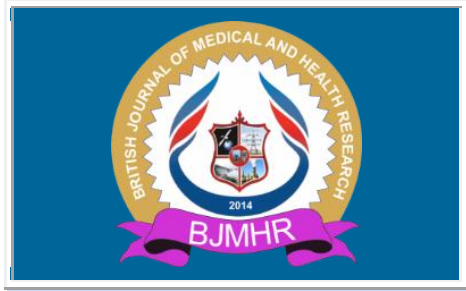

\title{
BJMHR
}

British Journal of Medical and Health Research

Journal home page: www.bjmhr.com

\section{Opinions of Health Administration Students about Current Medical Law Applications}

\author{
Gurkan Sert $^{1 *}$, Bahar Uslu ${ }^{2 *}$, Birkan Tapan ${ }^{3}$, Gulfer Bektas ${ }^{4}$, Albena GAYEF ${ }^{5}$ Sinem \\ Yildiz Inanici', \\ 1.Marmara University School of Medicine Department of Ethics and Medical History \\ 2.Yale School of Medicine Department of Obstetrics \& Gynecology \\ 3 Istanbul Bilim University, Faculty of Health Science, Health Management Department \\ 4 Acrbadem University, Faculty of Health Science, Health Management Department \\ 5 Trakya University Faculty of Medicine, Department of Medical Education 6.Marmara \\ University School of Medicine Medical Education Department
}

\begin{abstract}
Opinions of students about current medical law application were investigated. Students $(n=401)$ who participated in this study were enrolled in the health management undergraduate programs of various public and private universities. The data regarding important topics of medical law were gathered by questionnaires. In this study, the determination of the student concerns and some of their effects have been evaluated. It was found that the participants believed that patients tend to file lawsuits at high rates; current laws are not sufficient to protect healthcare workers; and regulations seem to protect patients more than health professionals. Legal refrain in health care workers may lead to behaviors that impede institutional goals and detract from patient-centered approaches.
\end{abstract}

Keywords: health management; medical law; medical ethics; health professionals; students 


\section{INTRODUCTION}

Health law and health management have increasingly become topics of discussion and research over the last years. (Zebiene 2004; Bostan 2007; Metin 2010; Kucuradi 2011; Tofan 2013, and Javaid 2015). For these reasons, some initiatives in Turkey have been carried out under the "Health Transformation Project". Within the scope of the project, changes have been made in the creation and management of primary, secondary and tertiary health care institutions and associations that provide health services in Turkey. (Health Transformation Program. 2008, Lamba 2014 and Altindis 2011) These rapid changes naturally increased the demand for health care managers and also health management programs. In this context, as well as undergraduate, graduate and doctoral education in health care administration, certificate programs are also continuing increasingly. (Health Management Education. 2010) Another important aspect of both graduate and post-graduate education programs is the creation of courses in "health law". Within the scope of these courses in graduate programs, Turkish and world health legislation- as well as important topics of medical law- are presented to students. There has also been an increased interest in this specialty field in the last years. Undergraduate and graduate programs have recently been introduced, and congresses have been organized on a variety of topics in health law. (Health Law Education. 2017)

In terms of the performance of health services, the views of the individuals involved are important to take into account in order to gain a fuller understanding of current issues in medical law and health care medicine in our country. The determination of health administrators' approaches to current problems of medical law and medical ethics can be used to produce new and better solutions. For example, in the context of the problems that have been identified, it may be possible to revise the contents of graduate and undergraduate courses in medical law, health legislation, and medical ethics so that they will be applicable to current real-life problems. The questionnaire we used in our study covered topics such as legal liability, patient rights, reporting obligation, and informed consent, including discussions in terms of medical law and ethics. These items were included to determine the opinions of the respondents on the field. It should be noted that the current problems of medical law and ethics in Turkey are not limited to the topics used in this study. In addition to the topics covered in the questions that are asked, there are also current problems in the topics such as research, organ transplantation, abortion and in vitro fertilization applications in human beings, including debates in terms of medical law and ethics. Structural and legislative changes of health care services play a role in the rapid development of health care law and health care management in Turkey. (Health Transformation Program. 2008; Lamba 
2014 and Altindis 2011) In this regard, there are observations and determinations that the legal framework, and thus the anxiety of encountering judicial processes, increases in health workers, which in turn affects the patient-centered approach of health workers in the negative way. (Assault on healthcare workers. 2016; Attack on healthcare workers. 2012; Akcakaya, 2017) From this point on, the concerns about the legal process have been determined and its effect on some approaches has been evaluated.

\section{MATERIALS AND METHOD}

This study's universe is composed of all the students $(n=1157)$ enrolled in the Departments of Health Institutions' Management programs of universities in Istanbul. The sample of the study contained 288 students with $95 \%$ confidence level and 5\% error margin. A total of 401 students were reached in the research. A socio-demographic form was applied with a questionnaire consisting of 33 items. These items were created by the researchers to determine the students' thoughts on current issues of medical law and patient rights. The socio-demographic questionnaire consisted of questions about the type of university, kind of secondary education, age, sex, class in which they were studying, status of internship in hospital, education about medical law, education about medical ethics. Participants were asked to rate each expression according to Likert Scale: 1. Strongly disagree, 2. Disagree, 3. Unsure, 4. Agree, 5. Strongly agree. In the analyzes, 5-point Likert classification is categorized as 3 categorical ( 1 = Disagree, 2 =Unsure, 3 = Agree).The data were evaluated by frequency, percentage, arithmetic mean and chi-square test. The level of significance was taken as 0.05 . Averages, frequency distributions and chi-square analyzes were performed using the SPSS 14.0 program. The demographic information of participants is shown in Table 1.

Table 1: Socio-demographic characteristics of students who consented to participate in the survey $(n=401)$

\begin{tabular}{|c|c|c|c|}
\hline Variables & 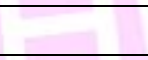 & n & $\%$ \\
\hline \multirow{4}{*}{ Gender } & Female & 254 & 63,3 \\
\hline & Male & 147 & 36,7 \\
\hline & Total & 401 & 100,0 \\
\hline & Private & 210 & 52,4 \\
\hline \multirow[t]{4}{*}{ University } & Public & 191 & 47,6 \\
\hline & Total & 401 & 100,0 \\
\hline & Class 1 & 163 & 40,6 \\
\hline & Class 2 & 113 & 28,2 \\
\hline \multirow[t]{3}{*}{ Class } & Class 3 & 81 & 20,2 \\
\hline & Class 4 & 44 & 11,0 \\
\hline & Total & 401 & 100,0 \\
\hline \multirow{2}{*}{ Internship at the hospital } & Yes & 155 & 38,7 \\
\hline & No & 246 & 61,3 \\
\hline
\end{tabular}




\begin{tabular}{llll}
\hline \multirow{3}{*}{ Medical law education status } & Total & 401 & 100,0 \\
& Yes & 98 & 24,4 \\
& No & 303 & 75,6 \\
& Total & 401 & 100,0 \\
& Yes & 92 & 23,0 \\
Medical ethics education status & No & 308 & 77,0 \\
& Total & 400 & 100,0 \\
\hline
\end{tabular}

\section{RESULTS AND DISCUSSION}

\section{Legal Refrain about laws}

In general, nearly half of the participants think that the new Penal Code causes more employees to be sued and that the legislation does not adequately protect healthcare workers. Approximately $80 \%$ of the participants $(n=300)$ believe that there should be a separate law on health practices. The indecisiveness is also remarkable in replies to these items (Table 2).

Table 2: Ideas on legal arrangements in the field of health

\begin{tabular}{lllllllll}
\hline & Disagree & \multicolumn{2}{l}{ Unsure } & \multicolumn{2}{l}{ Agree } & N \\
\hline Patients tend to sue health care workers & 76 & 19,0 & 92 & 23,0 & 232 & 58,0 & 400 \\
$\begin{array}{l}\text { The new Penalty? Code causes health workers to } \\
\text { be sued more frequently. }\end{array}$ & 45 & 11,6 & 160 & 41,3 & 182 & 47,0 & 387 \\
$\begin{array}{l}\text { Legal regulations protecting patient rights are } \\
\text { more widely used than regulations that protect }\end{array}$ & 67 & 17,0 & 98 & 24,9 & 229 & 58,1 & 394 \\
the rights of health workers. & & & & & & & \\
$\begin{array}{l}\text { The law does not adequately protect healthcare } \\
\text { workers. }\end{array}$ & 84 & 21,6 & 121 & 31,1 & 184 & 47,3 & 389 \\
$\begin{array}{l}\text { There should be a separate legal act (Malpractice } \\
\text { Law) for health care practice. }\end{array}$ & 23 & 6,0 & 62 & 16,1 & 300 & 77,9 & 385 \\
\hline
\end{tabular}

Table 2ab: Ideas on legal arrangements in the field of health

\begin{tabular}{llllllll}
\hline & \multicolumn{2}{c}{ Disagree } & \multicolumn{2}{c}{ Unsure } & \multicolumn{2}{c}{ Agree } & N \\
& $\mathbf{n}$ & $\mathbf{\%}$ & $\mathbf{n}$ & $\mathbf{\%}$ & $\mathbf{n}$ & $\mathbf{\%}$ & \\
\hline $\begin{array}{l}\text { The physician working in the public health } \\
\text { institution may refuse to look after the patient } \\
\text { except in emergency situations. }\end{array}$ & 273 & 69,1 & 46 & 11,6 & 76 & 19,2 & 395 \\
$\begin{array}{l}\text { The physician working in the private health } \\
\text { institution may refuse to look at the patient } \\
\text { except in emergency situations }\end{array}$ & 279 & 70,5 & 39 & 9,8 & 78 & 27,9 & 396 \\
\hline
\end{tabular}

Table 2c: Patient rights agenda and ideas for implementation

\begin{tabular}{|c|c|c|c|c|c|c|c|}
\hline & \multicolumn{2}{|c|}{ Disagree } & \multicolumn{2}{|c|}{ Unsure } & \multicolumn{2}{|c|}{ Agree } & \multirow[t]{2}{*}{$\mathbf{N}$} \\
\hline & n & $\%$ & n & $\%$ & n & $\%$ & \\
\hline $\begin{array}{l}\text { The fact that patient rights are on the agenda } \\
\text { makes it difficult to provide health services. }\end{array}$ & 202 & 51,1 & 97 & 24,6 & 96 & 24,3 & 395 \\
\hline $\begin{array}{l}\text { I think that health workers should be educated } \\
\text { about patient rights }\end{array}$ & 15 & 3,8 & 18 & 4,6 & 361 & 91,6 & 394 \\
\hline $\begin{array}{l}\text { I think that the patients should be educated } \\
\text { about patient rights }\end{array}$ & 13 & 3,3 & 16 & 4,1 & 362 & 92,6 & 391 \\
\hline
\end{tabular}


A significant correlation was found between receiving education on both medical law and medical ethics and the tendency to think that patients tend to sue health workers. According to this, students who are studying medical law and medical ethics think that patients are more likely to sue health workers than students who are not (Table 3 and 4).

Table 3: Opinions that patients tend to sue health workers / Medical law education

\begin{tabular}{|c|c|c|c|c|c|c|}
\hline Medical & Disagree & & & Agr & ongly & $\mathbf{N}$ \\
\hline Education & n $\%$ & $\mathbf{n}$ & $\%$ & $\mathrm{n}^{\circ}$ & $\%$ & \\
\hline Trained & 11.2 & 20 & 20.4 & 67 & 68.4 & 98 \\
\hline $\begin{array}{l}\text { Untrained } \\
*\left[\mathrm{X}^{2}(2)=7.03, \mathrm{p}=.030\right]\end{array}$ & 21.6 & 72 & 23.9 & 164 & 54.5 & 301 \\
\hline
\end{tabular}

Table 4: Opinions that patients tend to sue healthcare workers / medical ethics education

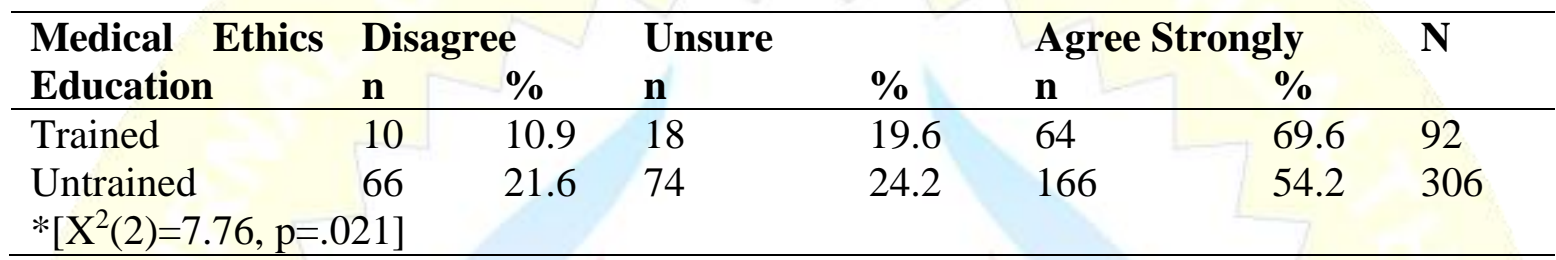

\section{Refusing to treat the patient}

Among the participants, $70 \%$ think that the physician should not refuse care to patients in private or public health institutions. In terms of possibility of rejecting the patients in private or public health institutions, there was a significant difference between the opinions of students in public and private universities, and also between female and male students. More students in public universities than private university students, and more male than female students think that physicians may refuse patient care. Students from private universities did not participate more than the public university students in the expression of "7. The physician working in the public health institution can refuse to treat the patient except for emergency conditions"(X2 = 16,399 $\mathrm{p}=, 000)$.

It was determined that the students in the private universities did not participate more than the public university students in the expression of "the physician working in the private health institution can refuse to look at the patient except the emergency cases" (X2 =14,057; p =, 001). (Table $2 \mathrm{ab}$ )

\section{Patient rights agenda and ideas for implementation}

Approximately half of the participants think that the formal expression of patient rights makes health services more difficult. $90 \%$ of participants think that both employees and patients should be educated about patient rights. There was also a significant difference between the opinions of those who studied medical law and students who did not. In terms of the need for required medical rights training for health professionals, female students are more favorable than male students, and those who have received medical law education are 
more favorable than those who have not. Students who received medical law education were more involved than students who did not in the expression "I think that health personnel should be educated about patient rights" $(\mathrm{X} 2=6,107 ; \mathrm{p}=, 047)$. (Table 2c)

\section{Opinions on Informed Consent Form}

While $50 \%$ of the participants agreed that the signing consent form by patient is sufficient in terms of informing the patient and fulfilling the physician's obligation in the judicial process, $25 \%$ were undecided. Approximately 60 percent of the participants believe that the most important goal of the consent form is to save the institution from responsibility. (Table 5)

Table 5: Meaning and Statement of Consent form

\begin{tabular}{|c|c|c|c|c|c|}
\hline Meaning of Consent Form & & & & & \\
\hline $\begin{array}{l}\text { The fact that the patient has signed the informed } \\
\text { consent form should be sufficient to prove that } \\
\text { the physician fulfills the obligation to enlighten } \\
\text { the judicial process. }\end{array}$ & 96 & $24,4 \quad 109$ & 27,7 & 189 & 48,0 \\
\hline $\begin{array}{l}\text { The most important function of the written } \\
\text { informed consent form rescues the institution } \\
\text { from responsibility. } \\
\text { Statement of Consent form }\end{array}$ & 79 & $20,2 \quad 80$ & 20,5 & 232 & 59,3 \\
\hline
\end{tabular}

\section{DISCUSSION AND CONCLUSION}

\section{Legal refrain about laws}

Issues such as legislative inadequacy, legal refrain regarding the judicial processes, and the consideration of the students "tendency to sue patients' health care workers" should be taken into account in the future considerations of the relationships between patients and health care workers. The fact that the staffs try to keep the patients under the pressure of the lawsuit has a significant negative impact on the trust relationship. (Health Transformation Program. 2008; Demonstration of health applications. 2014; Bostan 2007, and Agarwal 2012) This suggests that the employees are not confident in themselves or in the health worker-patient relationship, which should be based on mutual trust. (Sert 2004; Bostan 2007; Kaya 2006, and Agarwal 2012) Opinions of participants who are willing to take part in the presentation of health services may also lead to the planning and management of health institutions and organizations based on this understanding. (Bostan 2007; Kaya 2006; and Agarwal 2012) The reason why more students are involved in this idea than those who do not receive medical law and ethics is that it may be that concerns have been raised in the field of medical law and ethics training, increased awareness, or they are presented in an approach that emphasizes these concerns. Considering that patients tend to sue employees, it will bring significant obstacles in terms of fulfilling their duties and responsibilities within the framework of professional autonomy. (Ak 1997; Tzeng 2002; Teke 2007, and Uludag 2011) This will be 
the reason why employees take decisions under medical and administrative discretionary care. (Strasen 1988; Uludag 2011, and Agarwal 2012) The situation is more important when participants are thought to be health management students. An approach in this direction can challenge both the establishment of a trust relationship between patients and health workers, as well as the provision of services by employees in the context of professional autonomy and professional ethics. (Strasen 1988; Uludag 2011; Agarwal 2012, and Tofan 2013)

Another important related problem is why and how employees develop ideas in this regard. Consequently, it is necessary to investigate why participants are inclined to such a trend, to make determination in this respect and to find a solution in this context in terms of ensuring the trust relationship between the health provider and the patient. (Erdemir 2005; Veatch 2010; Metin 2010, and Kucuradi 2011) It should also be observed that the training offered in this context contains such a message. (Footnote) A significant proportion of students are concerned that the New Penal Code causes employees to be sued more frequently, that legislation does not adequately protect health care workers, that legal regulations about patient rights are being more widely used, that they are feeling indecisive and insecure towards the regulations. The Turkish Criminal Code that came into force in 1923 was renewed in 2004, though it had undergone many changes over the years. For example, the New Turkish Penal Code that became effective in 2005 triggered discussions and debates on medical practices. The new code has been criticized in many symposia, meetings and congresses in terms of its medical consequences and the possibility that it introduced, or intended to introduce, more severe conditions. The opinion has become widespread among health professionals that the new law will create difficulties in medical applications. (New Turkish Criminal law. 2005; Kaya 2006; Bostan 2007, and Uludag 2011) For the same reason, there is a growing belief that health workers will be sued more frequently. (Bostan 2007; Physician rights association opinion, 2015; and Elcigil 2011) It is possible that the students in the public sector are thinking that the new penal code causes the employees to be sued more than the students who are taking private education and the private students are indecisive in the same matter, the reasons may be related to the different institutions in which they are educated.

Foot Note: Students who attended medical law education were more likely to participate in the statement "Patients tend to sue health workers" than students who did not receive medical law education. $(X 2=7,030 ; p=, 030)$

Students who are studying medical ethics were more likely to participate in the statement "Patients tend to be sued by health care workers" than students who did not receive education. $(X 2=7.764, p=, 021)$ 
Observations in private facilities with less work load and with fewer patient groups may have caused students to think in this direction.

No part of our work has been measured in terms of the level of participants' knowledge of the content of the penal law or other legal regulations related to health. For this reason, there was no evaluation of the influence of the students' intellectual propensity on their thinking. It is not possible to present an explanatory result in this context with the current state of our work. However, it is possible to say that according to the current level of knowledge of the students, the legal regulations are not enough for the rights of the employees. The effect of whether, or not the participants have knowledge about the regulations to have this opinion should be examined carefully. A study that will measure the level of knowledge in this area would be able to make an opinion on the participants' attitudes due to their approach to legal regulations. More important than whether these concerns are in place or not are those students' concerns about this matter. Legal refrain and discomfort caused by legal regulations may cause the disruption in the execution of the profession, even though it may lead to the belief that employees will act more appropriately in their professions. For example, the number of rising medical cases will often lead to defensive medicine. (Morrison 1998; Elcigil 2011, and Jawaid 2015) It should be also stated that physicians will not be able to process medical interventions easily due to their skepticism. (Morrison 1998, Elcigil 2011, and Jawaid 2015) The view that there should be a separate legislation on health practices is the result of the current regulatory regime's insufficiency. There are two drafts prepared in this regard in Turkey. But there is no legislation yet. Provisions concerning the legal responsibility of health workers are scattered in different legal arrangements. (Demonstration of health applications. 2014) Instead of this dismissal of the arrangements for their responsibilities, employees are in favor of determining their responsibilities in a single legal act.

\section{Rejecting the patient}

The updates of patient rights have brought together the discussions of the rights of health workers and especially the rights of physicians. Even though they have different contents, some associations constructed by physicians and Turkish Physicians Association established and published documents of physicians' rights. (Physician rights association opinion, 2015) Although this issue is controversial in and compliance with health legislation, this issue remains among the current problems of Turkish medical law. Among the rights contained in these documents, perhaps the most controversial one is the limitations and legal endorsements of the physician's rejecting the patient. The rise of violence in health care settings also intensified the debate about the right to reject the patient. For example, the 
Turkish, Ministry of Health regulation "Ensuring the Safety of Employees" states that the health worker might withdraw from giving care to patients in cases of violence, and it envisaged the establishment of "Employee Rights and Security Units" (Regulation on the provision of patient and employee safety. 2011) Similarly, in an event that was reflected in administrative jurisdiction, the Council of State decided that the physician might withdraw from giving care to the patient when there is no trust between the physician and the patient. (Supreme Court decision. 2012) The fact that the participant students think that the physician cannot reject patients in private and public institutions despite these current discussions can be evaluated positively in terms of the accessibility and continuity of the health service. However, it should also be emphasized that the proportion of students who think that the physician can reject the patient or who are undecided in this regard is not low. It is important to clarify the reasons for opinions in this regard that the physician can refuse, reject the patient or in indecision in public or private health care institutions. This is necessary in order to remove the negative effects of refusing to give care to the patient, which is an important topic that creates tension between the health worker and the patient.

\section{Patient rights agenda and ideas for implementation}

\section{$\underline{\text { Unlimited use of patient rights makes Health Services difficult. }}$}

It is thought-provoking that the proportion of participants is close to half believes or undecided that patient rights on the agenda are making health care difficult. The idea that patient rights are barriers to employees and that these rights are against them can be effective at this result. Bostan and his colleagues also found that $35 \%$ of the health workers who participated in the study regard patients' rights are against to health workers (Bostan 2007). The developments on the subject over the last 5 years in the world and in the last 15 years work of the Turkish Ministry of Health have caused an intensive patient rights agenda in the health world. The intensive use of mechanisms created by Turkish Ministry of Health, which have recently established an unlimited complaint of patients, has resulted in the same intensity of defense writings of health workers. This process has put pressure on healthcare workers due to patient rights. (Health Transformation Program. 2008; Altindis 2011; Lamba 2014, and Demonstration of health applications. 2014) For this reason, the opinion has evoked in health workers that the patients are constantly suing and have tendency to complain about them. Even more, corner articles exist in health magazines subjecting the rights of patients are the cause of violence. (Assault on healthcare workers. 2016: Attack on healthcare workers. 2012; Akcakaya, 2017) The reasons for the conclusion that patient rights are making health services difficult must be carefully researched. In this context, it is important to take precautions about the difficulties of patient rights in health services and to prevent them. 
Otherwise, this approach will prevent patients from receiving services on appropriate conditions belongs to human rights.

\section{Patient Rights Education}

Observations of the participants, patients and employees have incomplete information about patient rights may be the reason for this belief. For example, in a study conducted with the aim of assessing the knowledge and attitudes of nurses working in a training hospital, it was found that almost half of the participants did not receive training on patient rights, $20 \%$ had never encountered the concept of patient rights, and 65\% had been informed through sources outside the school. (Teke, 2007) Likewise, in study conducted with the aim of using and knowing the nurses' and the physicians' feelings and thoughts regarding patients' rights, the physicians and nurses stated that they knew and defended some patient rights but they did not have enough knowledge about the subject, and did not make use of these rights in an adequate or sustained manner. (Kaya, 2006)

However, it should also be considered that the issue of patients' rights is a dynamic area that can change per the changes in health care and medical services, which may have motivated the participants to think about it.

\section{Opinions on Informed Consent Form}

The reason why the participants' opinions about this article are in this direction may be to ensure that the physicians are protected from judicial processes. It cannot be argued that the content of the consent form should be sufficient to prove that the obligation of enlightenment has been fulfilled without checking, whether, or not using appropriate text, language or ensuring appropriate environment and timing before intervention. (Cobanoglu 2009, and Metin 2010) Written Consent forms are undoubtedly important from the point of view of illumination. (Cobanoglu 2009; Patients' Rights Regulation 1998 and Erdemir 2005) However, it does not mean that the informed consent form can use as a proof, because of it is prepared and used appropriately for its purpose. Participation in the matter shows that rescue is the most important function of the informed consent form from the institutional responsibility also the existence of the concern indicates that the consent forms are using to reduce the of legal processes. (Guide to Clarified Consent Form. 2013, Regulation on the provision of patient and employee safety. 2011, and Celbis 2012) Approximately 60 percent of the participants believe that the most important goal of these forms is to save the institution from responsibility. In this context, it is necessary that the main purpose of the AO forms is to inform the patient, that they should be prepared within this scope, and that their subjects should be brought forward in medical related trainings. However, it should not be ruled out 
that the approaches taken by the health administrator candidates for both matters are due to the concerns they have experienced from the legal process.

\section{ACKNOWLEDGEMENTS}

We thank Professor Emeritus Robert Glen from University of New Haven for his helpful comments during the preparation of the article.

\section{REFERENCES}

1. Agarwal AK, Murinson BB. 2012. "New Dimensions in Patient-Physician Interaction: Values, Autonomy, and Medical Information in the Patient-Centered Clinical Encounter.” Rambam Maimonides Med J 3(3): e0017.

2. Ak J, Bausel BR, Mahrenhdz DM. 1997. "Patient satisfaction with nursing care in hospitals." Outcomes Manage Nurs Practice 1 (1): 20-28.

3. Akcakaya, A. 2017. Attack on healthcare workers. Physician rights association. URL: http://www.hekimhaklaridernegi.org/index.php?page=slider\&content=detail\&hid=34 8 (accessed May 19, 2017)

4. Altindis M. 2011. "In Health Services, transformation Management." Health thinking and medical culture platform. [In Turkish] URL. http://www.sdplatform.com/Yazilar/Kose-Yazilari/388/Saglik-hizmetlerinde-degisimyonetimi.aspx (accessed May 19, 2017)

5. Assault on healthcare workers. 2016. Yildirim Newspaper. URL: http://www.yildirimgazetesi.com/haber/saglikcilara-saldiri-33283.html (accessed May 19, 2017)

6. Attack on healthcare workers. 2012. Turkish Radio and Television. URL: http://www.trthaber.com/haber/turkiye/istanbulda-saglikcilara-saldiri-61551.html (accessed May 19, 2017)

7. Bostan,S. 2007. "Investigation of the Attitudes of Health Workers to Patients' Rights: Farabi Hospital Example" [In Turkish] Hacettepe Saglık İdaresi Dergisi, 1(10): 1-18.

8. Celbis O. 2012. Informed Consent Form Receiving and Legal Meaning. Turkish Society of Nephrology.

URL: http://www.tsn.org.tr/pdf/kongre2012/Salon2/Osman\%20celbis.pdf (accessed May 19, 2017)

9. Cobanoglu N. 2009. Medical Ethics. TR: Ankara. Eflatun press. Turkish Medical Ethics Regulation. [In Turkish] 1960. TR: Ankara. Resmi Gazete. 10436.

10. Demonstration of health applications. 2014. Turkish Ministry of Health. http://www.saglik.gov.tr/TR,2976/saglik-hizmetleri-genel-mudurlugunce-hazirlanangeleneksel-tamamlayici-alternatif-tip-uygulamalari-yonetmelik-taslagi-gorus-veonerilere-acilmistir.html (accessed May 19, 2017) 
11. Elcigil A. 2011. "Ethical Dilemmas Which is Faced by Pediatric Palliative Care Nurse: Review." Turkiye Klinikleri J Med Ethics 19(3): 196-203.

12. Erdemir AD, Elcioglu OS. 2000. "Patient and physician rights in medical ethics" [In Turkish] Turkiye Klinikleri J Med Ethics 42-44.

13. Erdemir AD. 2005. "Ethics Medical Ethics Principles of Medical Ethics and Ethics in Relation to Patient-Physician.” Journal of Ataturk Kultur Merkezi 15 (44): 27-72.

14. Guide to Clarified Consent Form. 2013. Turkish Physician's Union. http://www.ttb.org.tr/mevzuat/index.php?option=com_content\&view=article\&id=983 :onam\&Itemid=65 (accessed May 19, 2017)

15. Health Law Education. 2017. Ozyegin University. URL: https://www.ozyegin.edu.tr/tr/duyurular/50026516 (accessed May 19, 2017)

16. Health Management Education. 2010. Turkish Ministry of Health.

URL: http://www.saglik.gov.tr/TR,4724/universite-onayli-sertifika-egitim-programihastane-isletmeciligi-ve-saglik-yoneticiligi.html (accessed May 19, 2017)

17. Health Transformation Program. 2008. Turkish Ministry of Health. URL: https://sbu.saglik.gov.tr/Ekutuphane/kitaplar/turkiyeSDP.pdf (accessed May 19, 2017)

18. Jawaid SA. 2015. "Patient satisfaction, patient safety and increasing violence against healthcare professionals." Pak J Med Sci 31(1): 1-3.

19. Kaya, H., Acaroglu, R., Ast1, T., Kaya, N., Sendir, M. 2006. "Patient Rights According to Student Observations" [In Turkish] Turkiye Klinikleri J Med Ethics 14(3): 140-4.

20. Kucuradi I. 2011. Ethics. TR: Ankara. Institute of Turkey Philosophy press.

21. Lamba, M, Altan Y, Aktel, M, Kerman U. 2014. "Restructuring in the Ministry of Health: In terms of new public administration, one Evaluation." [In Turkish] Amme İdaresi Dergisi, 47 (1): 53-78

22. Metin S. 2010. Biomedical Ethics and Law. TR: Istanbul. Levha press.

23. Morrison JL, Lantos JD, Levinson W. 1998. "Aggression and Violence Directed Toward Physicians." J Gen Intern Med 13(8): 556-561.

24. New Turkish Criminal law. 2005. Turkish Ministry of Justice. URL: http://www.cezabb.adalet.gov.tr/mevzuat/5237.htm,

25. Ozen, M. 2006. Criticism on new 2005 Turkish criminal justice. Association of Turkish Physician. URL: http://tbbdergisi.barobirlik.org.tr/m2006-65-247

26. Patients' Rights Regulation. Turkish Government official newspaper. [In Turkish] 1998. TR: Ankara. Resmi Gazete. 23420. 
27. Physician rights association opinion, 2015. Physician rights association. URL: http://www.hekimhaklaridernegi.org/index.php?page=kurumsal\&content=detail\&part $=98$

28. Regulation on the provision of patient and employee safety. 2011. Turkish Government

Official

Newspaper.

URL: http://www.resmigazete.gov.tr/eskiler/2011/04/20110406-3.htm

29. Sert_G. 2004. Patients' Rights, International Relations and Medical Ethics._[In Turkish] Babil yayınları, TR: İstanbul.

30. Strasen L. 1988. "Incorporating patient satisfaction standards into quality of care measures." Jona. 18 (11): 5-6.

31. Supreme court decision. 2012. "Do health workers deserve withdrawal from service, a significant advisory decision from supreme court" [In Turkish] Medimagazin. URL: http://www.medimagazin.com.tr/saglik-calisanlari//tr-saglik-calisanlarinin-hizmettencekilme-hakki-var-mi-onemli-bir-danistay-karari-6-17-48897.html (accessed May 19, 2017)

32. Teke A, Ucar M, Demir C, Celen Ö, Karaalp T. 2007. "Evaluation of the Knowledge and Attitudes of Patients' Rights in Nurses Working in a Training Hospital" [In Turkish] TSK Koruyucu Hekimlik Bulteni 6(4).

33. Tofan G, Bodolica V, Spraggon M. 2013. "Governance mechanisms in the physicianpatient relationship: a literature review and conceptual framework." Health Expect 16(1): 14-31.

34. Tzeng HM, Keteftan S. 2002 "The relationship between nurses' job satisfaction and inpatient satisfaction: An exploratory study in a Taiwan teaching hospital." Journ Nurs Care Qual 16 (2): 39-49.

35. Uludag A. Physician 's Choice Practice in Hospitals in Terms of Patient Communication: A Comparative Study. 2011. TR: Konya. Selcuk University Press.

36. Veatch RM. 2010. The Basics of Bioethics. USA: NYC. Taylor \& Francis

37. Zebiene E, Razgauskas E, Basys V, Baubiniene A, Gurevicius R, Padaiga Z, et al. 2004. "Meeting patient's expectations in primary care consultations in Lithuania." International Journal For Quality in Health Care 16(1): 83-89.

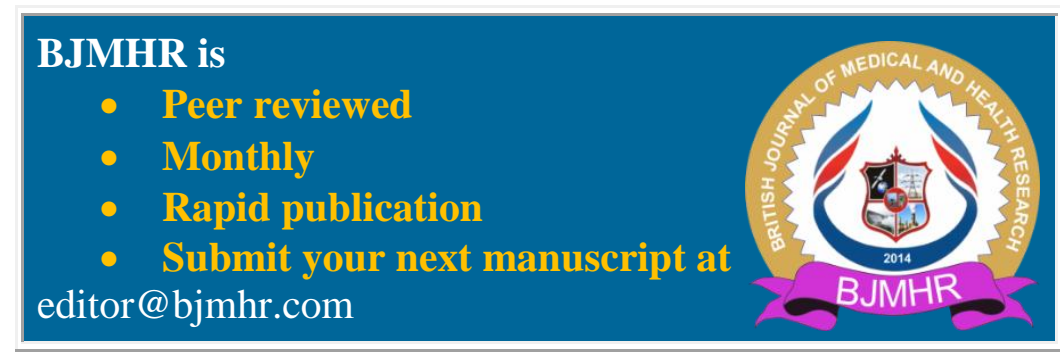

